\title{
Karakteristik dan Pendekatan Aspek Sosial Hukum Islam
}

\author{
Mudassir (dassir_mathar@yahoo.com) \\ Universitas Islam Negeri Alauddin Makassar, Sulawesi Selatan, Indonesia \\ Edi Gunawan (edigunawan@iain-manado.ac.id) \\ Intutut Aagama Islam Negeri Manado, Sulawesi Utara, Indonesia
}

\begin{abstract}
This article is a conceptual study of the characteristics and approaches of social aspects of Islamic law. This study is important because Islamic law encompasses various dimensions, namely the abstract dimension, in the form of all the commandments and the prohibitions of Allah and His Messenger, and the concrete dimension, in the form of behavior that is steady among Muslims as an effort to do the command of Allah and His Messenger, In addition, Islamic law also includes substances that are internalized into various social institutions. Therefore, the study of the social aspects approaches in Islamic law is very important. Islamic law has a character, namely rabbaniyah, syumul, al-wasthiyah, and insanity. There are several methods of Islamic law enforcement conducted by aspects of the social approach, especially in Indonesia, namely the establishment of Islamic law through fiqh, the establishment of Islamic law through the law, the establishment of Islamic law through jurisprudence, and the affirmation of Islamic law through fatwas.
\end{abstract}

Keynotes: Characteristics, Social AspectApproach, Islamic Law

\begin{abstract}
ABSTRAK
Artikel ini merupakan kajian konseptual tentang karakterisitk dan pendekatan aspek sosial hukum Islam. Kajian ini penting karena hukum Islam mencakup berbagai dimensi, yaitu dimensi abstrak, dalam wujud segala perintah dan larangan Allah dan Rasul-Nya, dan dimensi konkret, dalam wujud perilaku yang bersifat ajeg di kalangan orang Islam sebagai upaya untuk melaksanakan titah Allah dan Rasul-Nya itu. Selain itu, hukum Islam juga mencakup substansi yang terinternalisasi ke dalam berbagai pranata sosial. Oleh karena itu,
\end{abstract}


kajian tentang pendekatan aspek sosial dalam hukum Islam dipandang sangat penting. Hukum Islam memiliki karakter, yaitu rabbaniyah, syumul, al-wasthiyah, dan insaniyah. Ada beberapa metode penetapan hukum Islam yang dipengaruhi oleh aspek pendekatan sosial khususnya di Indonesia, yaitu penetapan hukum Islam melalui fikih, penetapan hukum Islam melalui undang-undang, penetapan hukum Islam melalui yurisprudensi, dan penetapan hukum Islam melalui fatwa.

Kata Kunci: Karakteristik, Pendekatan, Aspek Sosial, Hukum Islam 


\section{PENDAHULUAN}

Hukum Islam disebut dengan beberapa istilah atau nama yang masing-masing menggambarkan sisi atau karakteristik tertentu hukum tersebut. Sejak dahulu di kalangan umat Islam di dunia, tidak terkecuali di Indonesia, terjadi perdebatan dan perbedaan pendapat mengenai persepesi hukum Islam. Setidaknya ada beberapa nama yang sering dikaitkan dengan pengertian hukum Islam, serta menyamakan pengertian diantara syariah ${ }^{1}$, fiqih ${ }^{2}$ dan hukum Islam ${ }^{3}$. Kekacauan persepsi ini meliputi arti dan ruang lingkup pengertian syariah Islam yang kadang-kadang diartikan sama dengan fikih, bahkan adakalanya disamakan dengan ad-din.

Mempelajari sejarah sosial hukum Islam berarti mempelajari hukum itu sendiri. Hukum Islam telah berkembang secara kompleks sehingga melahirkan ulama dan

\footnotetext{
${ }^{1}$ Menurut Iskandar Usman, syariah adalah ajaran Islam yang sama sekali tidak dicampuri oleh adanya nalar manusia, syariah adalah wahyu Allah secara murni yang bersifat tetap, tidak bisa berubah dan tidak boleh diubah oleh siapa pun kecuali oleh yang Maha Mutlak yakni Allah itu sendiri. Lihat Iskandar Usman, Istihsan dan Pembaharuan Hukum Islam, Cet. I; Jakarta: PT. Raja Grafindo Persada, 1994), h. 104 sedangkan menurut Muhammad Ali al-Sayis yang dikutip oleh Umar Shihab, Syariah adalah hukum-hukum syarak mengenai perbuatan (manusia) yang dihasilkan dalil-dalil terinci. Yang dimaksud adalah adalah apa yang diperoleh dari ayat-ayat Alquran dan hadis Nabi saw yang sahih. Lihat Muhammad 'Ali al-Sayis, Nasy'ah alFiqh al-Ijtihad wa athwaruh, Salsalah al-Buhuts al-Islamiyah, Kairo, 1970, h. 8-9. Dalam Umar Shihab dalam Hukum Islam dan Transformasi Pemikiran, Cet. I; Semarang: Dina Utama Semarang, 1996), h. 11.

${ }^{2}$ Kata fikih secara etimologis, berakar pada kata atau huruf 0 ف yang menunjukkan kepada "maksud sesuatu" atau "ilmu pengetahuan". Itulah sebabnya, setiap ilmu yang berkaitan dengan sesuatu, disebut dengan fikih. Lihat Abi al-Husain Amhad bin Faris bin Zakariya, Mu'jam maqasyid al-Lu-ghah, Dar al-Fikr Li alThaba'ah wa al-Nasyr wa al-Tauzi, (t.tp, 1979, Juz III. h. 262. Dalam Umar Shihab dalam Hukum Islam dan Transformasi Pemikiran, h. 12. Sedangkan Menurut Abu Zahrah, mengemukakan bahwa fikih adalah mengetahui hukum-hukum syara' yang bersifat amaliah yang dikaji dari dalil-dalilnya yang terinci. Lihat Muhammad Zahrah, Ushul Fiqh, Cairo: Dar al-Fikr al-Arab, 1958. h. 6. Dalam Abdul Manah dalam Reformasi Hukum Islam di Indonesia, Cet. I; Jakarta: PT. Raja Grafindo Persada, 2006, h. 44. Menurut Abdul Manan, ada dua objek kajian fikih, yaitu hukum-hukum syara' yang bersifat amaliah dan dalil-dalil yang terpeinci dari Alquran dan Sunah yang menunjuk suatu kejadian tertentu, atau menjadi rujukan lagi kejadian-kejadian tertentu, seperti riba haram hukumnya karena telah ditetapkan dalam surat al-Baqarah: 279. Bahwa pengetahuan tentang hukum syara' itu didasarkan kepada dalil tafsili, dan fikih itu digali dan ditemukan melalui penalaran mujtahid. Abdul Manan, Reformasi Hukum Islam, h. 44.
}

${ }^{3}$ Menurut Amrullah dalam bukunya Dimensi Hukum Islam dalam Sistem Hukum Nasional menjelaskan bahwa hukum Islam adalah hukum yang diyakini memiliki keterkaitan dengan sumber dan ajaran Islam, yaitu hukum amali berupa interaksi sesama manusia, selain jinayat (pidana Islam). Lihat Amrullah Ahmad dkk, Dimensi Hukum Islam dalam Sistem Hukum Nasional (Cet. I; Jakarta: Gema Insani Press, 1996), h. 53. Dalam Supardin, Materi Hukum Islam, h. 22. Sedangkan dalam Kamus Hukum dijelaskan bahwa hukum Islam (Indonesia) atau hukum syara'ialah peraturan-peraturan dan ketentuan-ketentuan yang berkenan dengan kehidupan berdasarkan Alquran (Sudarsono, Kamus Hukum, Cet. II; Jakarta: PT. Rineka Cipta, 1999), h. 169. Hasbi Ashiddieqy berpendapat bahwa hukum Islam adalah bagian dari ilmu fikih. Karena ilmu fikih merupakan suatu kumpulan ilmu yang sangat luas pembahasannya, yang mengumpulkan berbagai ragam jenis hukum Islam dalam mengatur kehidupan seseorang, golongan, dan masyarakat secara umum. Hasbi Ash-Shiddieqy, Pengantar Hukum Islam, Edisi kedua (Cet. I; Semarang: PT. Pustaka Rizki Putra, 1997), h. 9. 
cendekiawan dengan karya tulisnya yang dijadikan sebagai khazanah yang tidak bisa dinilai dengan materi (Supardin, 2011:2).

Setiap hukum tentunya memiliki ciri-ciri dan karakteristik yang membedakan satu dengan yang lainnya. Karena itu, hukum Islam mudah dipahami dan bisa diterima di berbagai lapisan masyarakat. Bahkan di beberapa daerah hukum Islam telah menjadi peraturan daerah, yang bukan hanya wajib dipatuhi karena faktor keyakinan dan kepatuhan terhadap hukum agama, tetapi telah menjadi aturan yang wajib diikuti oleh setiap warga yang ada di daerah tersebut.

Hukum Islam sebagai tatanan dalam hukum modern dan salah satu sistem hukum yang berlaku di dunia ini, substansinya mencakup seluruh aspek kehidupan manusia, yakni, pertama, mencakup aspek ibadah, yaitu hukum-hukum yang mengatur hubungan manusia dengan al-Khaliq; kedua, mencakup hukum-hukum yang berhubungan dengan keluarga (alahwal asy syahșiyah) seperti nikah, talak, rujuk, wasiat, waris, dan hadhanah; ketiga, aspek muamalah (hukum sipil), yaitu hukum yang berhubungan dengan antarmanusia, seperti transaksi jual beli, gadai, hibah, utang piutang, pinjam meminjam, mudhārabah, joint usaha, luqāthah, dan sebagainya yang bertujuan mengatur agar terjadi keserasian dan ketertiban; keempat, mencakup aspek ekonomi, seperti hal-hal yang berkaitan dengan perkembangan kekayaan dan pemakaiannya, termasuk hukum zakat, baitul maal, harta ghanimah, fa'i, pajak dan hal-hal yang diharamkan seperti riba, menimbun harta, dan memakan harta anak yatim (Abdul Manan, 2006:62). Itulah beberapa hal yang menjadi bagian dari hukum Islam.

Berdasarkan pemaparan di atas, maka artikel ini membahas karakteristik dan pendekatan aspek sosial hukum Islam, yang dirumuskan dalam beberapa sub masalah sebagai berikut dengan subfokus pembahasan ialah (1) karakteristik hukum Islam dan (2) penerapan pendekatan aspek sosial dalam penetapan hukum Islam.

\section{KARAKTERISTIK HUKUM ISLAM}

Hukum Islam (Islamic law) adalah salah satu dari enam sistem hukum utama (major legal system) yang berlaku di dunia. Keenam sistem hukum itu adalah: 1) Islamic law, yaitu 
hukum yang berdasarkan al-Qurean, al-Sunnah dan ijtihad mujtahid; 2) Civil (Roman) law, yaitu hukum sipil kode sipil yang terkodifikasi. Sistem hukum ini berakar pada hukum Romawi (Roman law) yang dipraktikkan oleh negara-negara Eropa kontinental dan beberapa negara bekas jajahannya; 3) Common law, yaitu hukum yang berdasarkan custom atau kebiasaan, preseden atau judge made law (jurisprodensi hakim). Sistem hukum ini dipraktikkan di negera-negara Anglo Saxon, seperti Inggris dan Amerika; 4) Socialist law, yaitu sistem hukum yang dipraktikkan di negara-negara komunis; 5) Sub-saharan Africa, yaitu sistem hukum yang dipraktikkan di negara-negara Afrika yang berada di sebelah selatan gurun sahara; dan 6) Far east, yaitu sistem hukum yang komplek yang merupakn perpaduan antara sistem civil law, common law dan Islamic law sebagai basis fundamental masyarakat (Ade Maman Suherman, 2006:21-23).

Hukum Islam mencakup berbagai dimensi, yaitu dimensi abstrak, dalam wujud segala perintah dan larangan Allah dan Rasul-Nya, dan dimensi konkret, dalam wujud perilaku yang bersifat ajeg di kalangan orang Islam sebagai upaya untuk melaksanakan titah Allah dan Rasul-Nya itu. Lebih konkret lagi, dalam wujud perilaku manusia (amaliah), baik individual maupun kolektif. Hukum Islam juga mencakup substansi yang terinternalisasi ke dalam berbagai pranata sosial (Cik Hasan Bisri, 2004:31).

Hukum Islam memiliki karakter tersendiri, yang tidak memiliki kesamaan atau berbeda dengan karakteristik sistem hukum lain yang berlaku di dunia. Perbedaan itu disebabkan karena hukum Islam berasal dari Allah swt. yang bukan merupakan buatan manusia dan terlepas dari kepentingan individu maupun kelompok dan terbebas dari hawa nafsu. Salah satu contoh dari karakteristik hukum Islam yaitu menyedikitkan beban dan tidak memberatkan agar hukum yang diturunkan oleh Allah swt. dapat dilaksanakan oleh manusia sehingga dapat tercapai tujuan diturunkannya syariat dan manusia dapat mencapai kebahagiaan hidup di dunia maupun di akhirat.

Para pakar hukum Islam telah banyak membahas tentang karakteristik hukum Islam ini dengan berbagai literatur masing-masing. Namun, dalam membahas karakteristik ini mereka sependapat untuk berpedoman pada QS al-A'raf/7:157. 


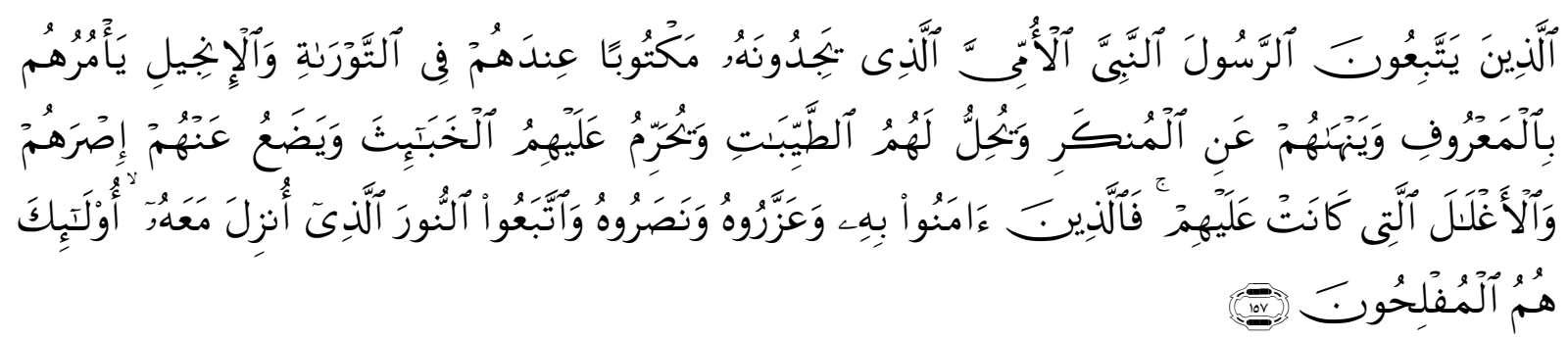

Terjemahnya:

(yaitu) orang-orang yang mengikut Rasul, Nabi yang ummi yang (namanya) mereka dapati tertulis di dalam Taurat dan Injil yang ada di sisi mereka, yang menyuruh mereka mengerjakan yang ma'ruf dan melarang mereka dari mengerjakan yang mungkar dan menghalalkan bagi mereka segala yang baik dan mengharamkan bagi mereka segala yang buruk dan membuang dari mereka beban-beban dan belenggu-belenggu yang ada pada mereka ${ }^{4}$. Maka orang-orang yang beriman kepadanya. memuliakannya, menolongnya dan mengikuti cahaya yang terang yang diturunkan kepadanya (Al-Qur'an), mereka Itulah orang-orang yang beruntung (Kementerian Agama RI, 2012:214).

Ayat tersebut menjelaskan bahwa yang semula manusia tidak ada batasnya untuk berperilaku, maka Allah memberikan batasan agar manusia berperilaku yang baik agar terarah dalam beribadah dan berperilaku. Agar manusia dapat melaksanakan perilaku yang baik itu, Allah memberikan kelonggaran dan kemudahan agar apa yang telah diperintahkan oleh Allah dapat dilakasanakan sebagaimana mestinya (Abdul Manan, 2006:95). Setiap manusia memiliki fitra kebaikan, maka manusia harus mampu berperilaku sebagaimana fitrahnya, yaitu melakukan kebaikan. Dalam bertindak dan berperilaku, manusia tentu dibatasi oleh aturan-aturan yang telah diturunkan oleh Allah swt., agar manusia tidak bertindak melebihi batasan-batasan syariah.

${ }^{4}$ Maksudnya: dalam syari'at yang dibawa oleh Muhammad itu tidak ada lagi beban-beban yang berat yang dipikulkan kepada Bani Israil. Umpamanya: mensyari'atkan membunuh diri untuk sahnya taubat, mewajibkan qisas pada pembunuhan baik yang disengaja atau tidak tanpa membolehkan membayar diat, memotong anggota badan yang melakukan kesalahan, membuang atau menggunting kain yang kena najis. Menurut Abdul Manan, maksud ayat tersebut bahwa Allah menyuruh mereka yang ma'ruf dan melarang mereka mengerjakan yang mungkar dan menghalalkan bagi mereka segala yang baik dan mengharamkan bagi mereka segala yang buruk dan membuang dari mereka beban-beban dan belenggu-belenggu yang ada pada mereka. Maka orang-orang yang beriman kepada-Nya, memuliakan-Nya, menolong-Nya dan mengikuti cahaya yang terang yang diturunkan kepadanya, mereka itulah orang-orang yang beruntung. (Abdul Manan, 2006:9). 
Hukum Islam mempunyai karakteristik tersendiri, berbeda dengan hukum Barat dan hukum adat, yang mempunyai dimensi ganda, menurut Eko Siswanto, karakteristik hukum Islam adalah pertama dimensi syariat (memiliki ciri wahyu) dan fikih (memiliki ciri ra'yu), kedua, ketuhanan dan kemanusiaan (iman dan ikhsan, atau akidah dan akhlak), ketiga, hukum Islam berwatak universal (mengatasi ruang dan waktu, mencakup bidang ibadah dan muamalat dalam arti luas, balasan atau sanksi dunia dan akhirat) dan kontekstual (dinamis), fleksibel) (Eko Siswanto, 2012:14).

Beberapa ahli hukum Islam berbeda pendapat dalam mengemukakan karakteristik hukum Islam ${ }^{5}$. Berikut ini, akan dijabarkan beberapa karakteristik hukum Islam, sebagai berikut;

\section{DIMENSI SYARIAT DAN FIKIH}

Dimensi syariat dan fikih mempunyai dua istilah kunci, yaitu syariat ${ }^{6}$ dan fikih. Syariat terdiri atas wahyu Allah dan sunnah Nabi Muhammad saw. dan fikih adalah pemahaman serta hasil pemahaman manusia tentang syariat. Syariat tidak dapat disamakan dengan fikih, tetapi kedua-keduanya tidak bisa dipisahkan.

Menurut Hamka Haq, istilah syariat pada awalnya mempunyai arti yang luas, tidak hanya berarti fikih dan hukum, tetapi mencakup pula akidah dan segala yang diperintahkan Allah swt. syariat dalam hal ini meliputi ajaran Islam secara keseluruhan yang disebut aldin. Namun dikemudian hari, pengertian syariat mengalami penyempitan, dipahami secara

${ }^{5}$ Hasbi Ash-Shiddieqy misalnya menyebutkan beberapa karateristik hukum Islam, yaitu sempurna (ta'amul), harmonis (washatiyah), dan dinamis (harakah). Lihat kembali Hasbi Ash-Shiddieqy, Filsafat Hukum Islam, h. 105-108. Muhammad Ali al-Sayih mengemukakan pendapat yang lain tentang karakteristik hukum Islam yang paling menonjol, yakni, tidak menyusahkan dan selalu menghindari kesusahan dalam pelaksanannya, menjaga kemaslahatan manusia dan selalu melaksanakan keadilan dalam penerapannya. Lihat pula Muhammad Ali al-Sayih Tarikh al Fiqh al-Islam, makalah wa Matba'ah Muhammad Ali Sabih wa Awladuh, Qoriah, Mesir, t.th, h. 25 dalam Abdul Manan, Reformasi Hukum Islam, h. 95. Namun demikian, maksud dari karakteristik yang dikemukakan oleh para ahli hukum Islam pada dasarnya memiliki maksud yang sama dan tetap pada prinsip-prinsip dalam QS. al-A'raf ayat 157, yang intinya tidak menyusahkan, tidak memberatkan, memberikan kelonggaran, serta sesuai dengan kemaslahatan umat manusia secara umum.

${ }^{6}$ Secara etimologi, kata syariat berakar pada kata شرع yang berarti "sesuatu yang dibuka secara lebar kepadanya". Dari pengertian inilah terbentuk kata شريعة yang artinya "sumber air minum”. Lihat Abi al-Husain Ahmad bin Faris bin Zakariya, Mu’jam Maqāyis al-Lugah, Juz III (t.c,t.t: Dar al-Fikr li al-Taba’ah wa al-Nasyr wa al-Tauzi, 1979), h. 262. 
terbatas dalam arti fikih dan identik dengan hukum Islam (Hamka Haq, 2000:7-8). Jadi syariat dapat dipahami bahwa ia berasal sepenuhnya dari Allah swt. sedangkan fikih hanya merupakan hasil pemikiran oleh para ahli hukum Islam (fukaha) terhadap suatu hukum permasalahan. Sehingga fikih akan selalu mengalami perkembangan berdasarkan waktu dan tempat di mana hukum itu ditetapkan. Sedangkan syariat akan berlaku sepanjang masa, di mana pun dan kapan pun waktunya, hukumnya akan tetap tanpa dipengaruhi oleh zaman.

\section{KETUHANAN (RABBANIYAH)}

Hukum Islam memiliki kelebihan yang tidak dimiliki oleh semua undang-undang buatan manusia dalam berbagai segi dan makna. Hukum buatan manusia hanya seperangkat peraturan yang bersifat materil dan keduniawian semata. Hukum-hukum yang terkandung di dalamnya terbatas kepada memelihara hal-hal yang bersifat zahir saja, dan tidak ada pemikiran halal-haram, tidak ada hal-hal yang bersifat batin dalam hubungannya dengan Kha>liq (sang pencipta). Oleh karena itu, jika badan legislatif dan yudikatif lemah atau lembaga hukumnya salah, sementara terdakwa mampu membebaskan diri dari tuduhan yang diajukan kepadanya, maka hal tersebut diterima tanpa dosa dan keadilan tetap dikesampingkan (Abdul Manan, 2006:96).

Menurut Eko Siswanto, kalimat syaha $>$ datain (asyhadu alla $>$ ila $>$ ha illalla $>h w a$ asyhadu anna muhammadan rasu>lulla>h), tidak hanya berhubungan dengan ketauhidan atau akidah saja, tetapi ungkapan ini juga mengandung syariat, jika dialihkan ke dalam bahasa hukum akan berbunyi "tiada hukum kecuali hukum Allah" (Eko Siswanto, 2012:15). Itu artinya bahwa hukum itu hanya bersumber dari satu hukum, yaitu hukum yang berasal dari Allah swt. dan hukum tersebut berlaku di dunia dan akhirat, serta dapat membawa manusia untuk kebahagian di dunia dan akhirat. Sedangkan hukum yang dibuat oleh manusia, hanya berlaku untuk kehidupan dunia, dan belum tentu dapat membawa kepada kemaslahatan.

Hukum Islam adalah hukum yang diciptakan untuk memenuhi kebutuhan jasmani dan rohani, dunia dan akhirat. Dalam pelaksanaannya sangat tergantung pada iman dan akhlak, di 
samping tergantung pada kekuatan dan kekuasaan. Hukum Islam memberikan balasan akhirat di samping balasan dunia. Oleh karena itu, penghormatan dan ketaatan terhadap syariat yang cemerlang ini tidak hanya terbatas pada hukum-hukum yang nashnya bersumber dari Alquran dan Sunnah saja, tetapi juga mencakup berbagai hukum hasil ijtihad dan peraturan-peraturan lain yang dikeluarkan oleh negara dalam memelihara kemaslahatan umum, seperti peraturan lalu lintas, perpajakan, dan sebagainya (Abdul Manan, 2006:96). Menaati peraturan yang dibuat oleh negara merupakan sesuatu hal yang wajib diikuti berdasarkan QS an-Nisa/4:59, "Hai orang-orang yang beriman, taatlah kepada Allah, kepada Rasul, dan Ulil Amri (pemimpin) di antara kamu” (Kementerian Agama RI, 2012:114).

\section{UNIVERSAL (SYUMUL)}

Salah satu fakta yang tidak dapat diingkari adalah bahwa hukum Islam telah berlaku pada hampir di seluruh dunia dengan kelebihannya dan kekurangannya, keragaman bahasa dan peradabannya, sesuai dengan perubahan waktu dan zamannya. Hukum Islam telah mampu memenuhi berbagai keperluan masyarakat dan mampu mendiagnosis berbagai penyakit dan problema yang timbul dalam kehidupan dengan cara aman, tertib, dan adil. Hukum Islam tampil sebagai undang-undang yang diagungkan di negara-negara Islam sekitar 13 abad lamanya sampai datangnya masa imperialisme Barat yang menggantikannya sebagai qanun buatan manusia.

Hal tersebut dapat terlaksana dengan baik karena hukum Islam di samping memiliki keteguhan dasar dan akar yang kuat terhadap akal dan keluhuran fitrah, pemeliharaan realitas, tawāzun antara hak dan kewajiban, rohani dan jasmani, dunia dan akhirat yang dibangun atas fondasi keadilan. Hukum Islam juga memiliki sifat elastis (murūnah) yang menakjubkan sehingga menjadikannya fleksibel terhadap masalah baru dan mampu mengatasi berbagai dilema zaman modern. Hukum Islam memiliki karakter syumul (universal) yang meliputi semua zaman dalam kehidupan dan eksistensi manusia. Hukum Islam adalah hukum untuk semua zaman dan generasi, bukan hukum yang terbatas oleh masa dan tempat yang implementasinya berakhir seiring dengan berakhirnya zaman tersebut, 
seperti yang terjadi pada para nabi pembawa hukum sebelum Nabi Muhammad saw. diangkat sebagai Rasul 7 .

Menurut Eko Siswanto, universalitas hukum Islam dapat dilihat dari aspek kualitatif, mengenai ruang dan waktu, dan berlaku abadi. Dari aspek kuantitatif hukum Islam, didasarkan pada kerangka hukum yang ditetapkan oleh Allah swt., tidak hanya mengatur hubungan manusia dengan manusia lain dan benda dalam masyarakat, tetapi juga mengatur hubungan manusia dengan Allah swt., hubungan manusia dengan dirinya sendiri, dan hubungan manusia dengan alam sekitarnya (Eko Siswanto, 2012:20). Dalam penerapan hukum Islam yang telah ditetapkan oleh Allah swt., tidak dipengaruhi oleh suku, jenis kelamin, kebangsaan, golongan, rakyat, pejabat, penguasa, bahkan raja sekalipun.

Hukum Islam, selain bersifat universal, juga memiliki karakteristik kontekstual, Eko Siswanto mengutip pendapat Yusuf al-Qardha>wi berdasarkan kaidah-kaidah dan pola-pola berpikir, antara lain: a) memudahkan dan menghilangkan kesulitan; b) memperhatikan tahapan masa; c) turun dari nilai ideal menuju realita dalam situasi darurat; d) segala yang mendatangkan kerugian atau kesengsaraan umat harus dilenyapkan; e) kemudharatan tidak boleh dihilangkan dengan kemudharatan; f) kemudharatan yang bersifat khas digunakan untuk kemudharatan yang bersifat umum; g) kemudharatan yang ringan digunakan untuk menolak kemudharatan yang berat; h) keadaan terpaksa memudahkan perbuatan atau tindakan terlarang; i) apa yang dibolehkan karena terpaksa, diukur menurut ukuran yang diperlukan; j) kesulitan mendatangkan kemudahan; k) menutup sumber kerusakan didahulukan atas mendatangkan kemaslahatan (Eko Siswanto, 2012:20).

\footnotetext{
${ }^{7}$ Abdul Manan, Reforamsi Hukum Islam di Indonesia, h. 98. Abdul Manan mengutip pendapat Hasan al-Banna dalam tulisan Yusuf al-Qardhāwi, Karakteristik Islam Kajian Analitik (Surabaya: Rislaah Gusti, 1995), h. 117, mengungkapkan bahwa jangkauan syumul dalam risalah Islam (termasuk hukum-hukum di dalamnya) adalah risalah yang menyeluruh yang meliputi abad sepanjang zaman, terhampar luas sehingga meliputi semua cakrawala umat, begitu mendalam dan mendetail sehingga memuat semua urusan dunia dan akhirat dalam mengatur hidup manusia di dunia. Sejalan dengan itu. Yusuf al-Qardhawi juga mengemukakan bahwa syumul dalam syariat Islam adalah memeberikan pengertian kepada seluruh umat manusia bahwa Islam adalah risalah bagi umat manusia dalam semua sektor kehidupan manusia dan aktivitasnya. Islam tidak pernah meninggalkan satu aspek pun dari aspek kehidupan manusia kecuali di dalamnya ada sikap yang harus dilakukannya. Aspek-aspek tersebut kadang lahir dari keputusan atau penetapan dalam bentuk pelurusan dan perbaikan, penyempurnaan dan perubahan, melalui nasihat dan pengarahan, melalui qanun dan peraturan negara lainnya, terkadang dengan cara hukuman bagi seseorang yang semuanya diletakkan pada posisinya secara proporsional. Lihat Yusuf al-Qardhawi, Karakterstik Islam Kajian Analitik, h. 125-137
} 
Syümuliyah hukum Islam mencakup apa saja yang berhubungan dengan permasalahan keluarga, yaiu masalah pernikahan, perceraian, nafkah, penyusuan, kewarisan, penguasaan terhadap diri dan harta mencakup segala hal yang disebut al-ahwal asy-syahsyiyah atau masalah-masalah individu dan keluarga. Selain itu juga mencakup hukum-hukum yang berhubungan dengan perdagangan, moneter, bisnis dan apa saja yang berhubungan dengan tukar-menukar harta benda maupun kepentingan lainnya dengan atau tanpa imbalan, seperti jual beli, sewa menyewa, peminjaman, utang piutang, gadai, wesel, jaminan, asuransi, dan sebagainya. Juga berhubungan dengan masalah jinayah, hudud, kriminal, qiyas dan sebagainya. Hukum Islam juga mencakup hal-hal yang berkaitan dengan kewajiban negara terhadap rakyat dan sebaliknya serta pengaturan komunikasi antar keduanya, termasuk juga hukum-hukum internasional dan politik negara (Abdul Manan, 2006:99-100).

Hukum Islam memiliki keistimewaan dengan karateristiknya yang syu>mul, karena hukum Islam meliputi segala persoalan yang berkaitan dengan kehidupan manusia. Apa pun akitivitas yang akan dilakukan oleh manusia selalu mendapat bimbingan dari Allah swt. melalui hukum-hukum Allah. Dalam hal ini Islam memandang bahwa pada dasarnya kehidupan ini merupakan satu kesatuan yang tidak terpisah dari yang lainnya, misalnya agama tidak terpisahkan dari masalah ibadah, ekonomi, akhlak, keluarga, masyarakat, negara dan lain sebagainya.

\section{HARMONIS (AL-WASTHIYYAH)}

Karakteristik harmonis (al-wasthiyyah) mempunyai arti yang sama dengan keseimbangan (al-tawāzun) yang mempunyai arti keseimbangan di antara dua jalan atau dua arah yang saling berhadapan atau bertentangan, di mana salah satunya tidak dapat berpengaruh dengan sendirinya dan mengabaikan yang lain serta tidak dapat mengambil hak yang lebih banyak melampaui yang lain. Contoh dua arah yang berlawanan adalah nuhiyyah (spiritualisme) dengan maddiyah (materialisme), fardhiyah (individu) dengan jama'iyah (kolektif), waqi'iyah (kontekstual) dengan mitsaliyyah (idealisme), satbah (konsisten) dengan taqhayyun (perubahan), dan sebagainya (Yusuf al-Qardhawi, 1995:141). 
Hukum Islam menempuh jalan tengah (wasathan) pada setiap masalah yang dihadapi, yaitu jalan yang seimbang, tidak terlalu berat ke kanan karena mementingkan kejiwaan dan tidak berat ke kiri karena mementingkan kebendaan. Hukum Islam selalu menyelaraskan antara fakta yang ideal dengan cita-cita seperti yang tersebut dalam Alquran dan hadis. Hukum Islam terletak antara pikiran-pikiran manusia yang cenderung kepada kejiwaan dengan pikiran-pikiran yang cenderung kebendaan. Hukum Islam tidak bersifat kapitalis ataupun marxisme, tidak terlalu mementingkan inidividu dan tidak mementingkan rohaniah. Hukum Islam posisinya di tengah-tengah antara kecenderungan maddiyah dengan kecenderungan rohaniah(Abdul Manan, 2006:101).

Hukum Islam tidak meletakkan individu di bawah tekanan masyarakat, tidak menjadikan individu budak masyarakat. Hukum Islam memberikan kepada individu harga diri, kebebasan berpikir dan bergerak. Hukum Islam senantiasa mempertautkan manusia dengan Allah dan mempertautkan sesama manusia serta mengarahkan kedua pertautan tersebut. Hukum Islam tidak memisahkan antara kehidupan dunia dan akhirat. Hukum Islam mengadakan hubungan yang erat antara agama dan negara dan sebaliknya. Dalam hal ini hukum Islam berbeda dengan sistem hukum yang berlaku di negara-negara Barat yang memisahkan antara masalah-masalah kepercayaan dengan masalah-masalah kehidupan masing-masing dipimpin oleh lembaga-lembaga tertentu. Hukum Islam membuka lapangan yang luas untuk berkembang sehingga mempunyai sifat yang konstan, stabil dan fleksibel serta mempunyai daya elastis(Hasbi ash-Shiddieqy, 1997:106-114).

\section{MANUSIAWI (INSANIYAH)}

Makna karakteristik hukum Islam yang bersifat manusiawi adalah bahwa hukum Islam diperuntukkan untuk meningkatkan taraf hidup manusia, membimbing dan memelihara sifat-sifat humanistiknya serta menjaga dari sifat jahat hewani agar tidak mengalahkan sifat kemanusiannya. Agar hal ini dapat terlaksana, hukum Islam memformulasikan dirinya dalam bentuk ibadah bagi manusia untuk memenuhi keperluan rohanianya. Bersamaan dengan perhatiannya terhadap rohani ini, hukum Islam tidak pernah melupakan aspek raga dan 
keperluan-keperluannya. Hukum Islam memotivasi manusia untuk berjalan di muka bumi mencari karunia Allah dan berusaha untuk memakmurkan bumi ini dengan menganjurkan manusia agar berbuat baik sesamanya dan tidak bermusuh-musuhan(Abdul Manan, 2006:104).

Hasbi ash-Shiddieqy mengemukakan bahwa karakteristik hukum Islam bersifat insaniyah tiada lain adalah pengakuan Allah terhadap kemuliaan manusia karena kemanusiannya. Hukum Islam tidak mendahulukan sesuatu pun atas manusia, manusialah yang menjadi jauhar dan asasnya, daripadanyalah bercabang segala khususīyah dan sifat, segala mazìyah dan fadhỉlah. Sehubungan dengan hal ini, hukum Islam tidak membenarkan segala bentuk pelecehan terhadap manusia dan menumpahkan darahnya tanpa alasan yang dibenarkan oleh hukum. Jalan yang ditempuh dalam menghadapi orang-orang jahat, hendaknya ditempuh dengan jalan sebagaimana yang telah ditetapkan oleh syara'. Hukum yang harus dilaksanakan itu hendaknya ditetapkan atas dasar memelihara kemuliaan manusia, bukan atas dasar kebencian dan balas dendam (Hasbi Ash-Shiddieqy, 1997:160).

Abdul Ghofur Anshori mengemukakan beberapa karakteristik hukum Islam (Abdul Ghofur Anshori dan Yulkarnain Harahab, 2008:36-37), antara lain:

a. Hukum Islam merupakan bagian dari agama Islam sehingga hukum Islam bersumber dari agama Islam dan tidak mungkin bertentangan dengan agama Islam;

b. Hukum Islam merupakan salah satu bagian dari tiga kerangka dasar Islam yang disebut sebagai syariah. Oleh karenanya, hukum Islam tidak terlepas dari akidah dan akhlak;

c. Hukum Islam bersifat universal, tidak lekang oleh zaman dan tidak lapuk oleh waktu. Hal ini dikarenakan hukum Islam terdiri dari dua aspek. Pertama, syariah sebagai ketentuan yang final, stagnan dan pasti (qat'i). Kedua, fikih sebagai ketentuan yang dapat diperbaharui, dinamis dan zanni yang menjadi antisipator atas perkembangan zaman;

d. Hukum Islam (fikih) ditemukan dan digali dengan menggunakan metode ushul fikih;

e. Hukum Islam mengatur manusia sebagai individu sekaligus mengatur manusia sebagai bagian dari masyarakat; 
f. Hukum Islam (syariah) diterima dan dilaksanakan oleh setiap muslim berdasarkan pada kerelaan (konsekuensi dari syahadat) pada dirinya untuk menjalankannya. Atau dapat dikatakan bahwa berlakunya hukum Islam (syariah) pada umat muslim adalah berbanding lurus dengan kondisi keimanan umat;

g. Hukum Islam eksistensinya adalah untuk menjamin kemaslahatan manusia. Oleh karenanya, hukum Islam menghormati manusia sebagai kesatuan jiwa dan raga serta memelihara kemuliaan manusia dan kemanusiaan secara keseluruhan;

h. Hukum Islam berlaku dengan mendasarkan pada tingkatan kemaslahatan. Yakni untuk menjamin terpenuhinya kemaslahatan ḍaruriyat, mewujudkan kemaslahatan hajjīyat dan terlakasananya tahsiniyat;

i. Hukum Islam selalu mendahulukan kewajiban dari hak dan mendahulukan amal dari pahala;

j. Hukum Islam dapat dibagi menjadi hukum taklifi dan hukum wad'i. Hukum taklifi terdiri dari lima kaidah yang dikenal dengan al-ahkam al-khamsah, yakni wajib, sunnah, haram, makruh, dan mubah. Sedangkan hukum wad'i terdiri dari sebab, syarat, dan halangan (mani) untuk terwujudnya atau terlaksananya suatu hukum.

\section{PENDEKATAN ASPEK SOSIAL DALAM PENETAPAN HUKUM ISLAM}

Sosiologi hukum maupun sosilogi hukum Islam merupakan ilmu pengetahuan yang relatif baru dalam perkembangannya. Salah satu dari kegunaan sosiologi hukum Islam antara lain menganalisa pengaruh timbal balik antara dinamika perubahan hukum dengan perubahan yang terjadi pada suatu masyarakat. Wilayah kajian sosiologi hukum tidak hanya diseputar dunia ilmu hukum saja, akan tetapi meliputi hukum yang hidup di masyarakat (living law).

Ilmu sosial dapat digunakan sebagai salah satu pendekatan untuk memahami hukum Islam. Hal ini disebabkan karena banyak bidang kajian dalam agama yang baru bisa dipahami secara proporsional apabila menggunakan pendekatan ilmu sosial. Menggunakan pendekatan sosial dalam memahami hukum Islam tidaklah bisa dihindari, karena tidak dapat dipungkiri bahwa sebagian hukum Islam itu berkaitan erat dengan masalah sosial. Oleh karena itu, 
sebagian ahli hukum Islam berusaha untuk memahami ilmu-ilmu sosial sebagai salah satu alat untuk memahami hukum Islam. Pendekatan ilmu sosial ini digunakan untuk memahami apakah perilaku seseorang di masyarakat sesuai dengan hukum Islam yang berlaku.

Krisis metodologi keilmuan Islam, yang berpangkal pada kurangnya dimensi empirisitas serta tidak adanya sistematisasi secara menyeluruh, disadari oleh para pemikir muslim sebagai persoalan yang harus segera mendapatkan terapi intelektual ${ }^{8}$. Akan tetapi, kekurangan tersebut tidak dapat semata-mata ditutup atau diganti dengan menerapkan ilmuilmu sosial modern Barat. Hal itu disebabkan karena metode dan pendekatan ilmu-ilmu sosial modern juga tengah mengalami krisis epistemologis yang tidak kalah akutnya. Jika metode dan pendekatan keilmuan Islam terjebak pada analisis tekstual dan kurang mengapresiasi dimensi sosial-empiris, maka sebaliknya, keilmuan Barat terjebak pada positivisme yang tidak pernah memperhitungkan dimensi normatif (wahyu) dalam metode dan pendekatannya(Mahsun Fuad, 2011:388).

Faktor-faktor sosial budaya yang senantiasa berkembang karena perkembangan ilmu pengetahuan dan teknologi telah merasuki berbagai pemikiran hukum Islam dewasa ini (Achmad Musyahid, 2012:124). Hal tersebut disebabkan karena tuntutan perubahan zaman, tidak hanya itu pemikiran dalam hukum Islam juga dimaksudkan untuk merespon berbagai perkembangan sosial budaya dari para pelaku pelaksana hukum. Berikut ini akan dijabarkan beberapa pemikiran dalam hukum Islam yang dipengaruhi oleh faktor sosial budaya, sebagai berikut:

\section{ASPEK SOSIAL BUDAYA DALAM YURSPRUDENSI}

Sejak lahirnya UU No. 1 Tahun 1974 tentang Perkawinan, terjadi perubahan hukum yang sangat signifikan dalam hukum Islam di Indonesia. Pemberlakuan undang-undang tersebut ditandai dengan dikeluarkannya PP No. 9 Tahun 1975. Pemberlakuan UU No. 1 Tahun 1974 tentang Perkawinan diikuti dengan ditetapkannya Inpres Presiden No. 1 Tahun

\footnotetext{
${ }^{8}$ Abdul Hamid A. Abu Sulayman dalam, Towards an Islamic Theory of International Relation, hlm. 87-92, 92-96. Idem, Crisis in the Muslim Mind, hlm. 43-63. Dalam Mahsun Fuad, Hukum Islam dan Sosial Vol. 11 No. 2 (Nopember 2011), h. 387.
} 
1991 tentang KHI. Munculnya beberapa undang-undang yang menampung hukum Islam membawa angin segar tentang pembaruan hukum Islam di Indonesia. Pembaruan yang ada berkaitan hukum keluarga yang dulunya dalam bidang fikih kemudian dimuat dalam peraturan perundang-undangan yang menjadi hukum nasional.

Pembaruan hukum Islam yang terjadi dalam bidang-bidang hukum keluarga ${ }^{9}$ merupakan keniscayaan yang disebabkan nilai-nilai yang terkandung dalam kitab-kitab fikih tidak mampu lagi memberikan solusi terhadap berbagai permasalahan kontemporer yang belum muncul pada waktu kitab-kitab fikih tersebut ditulis. Beberapa nilai-nilai fikih yang telah diperbaharui sebagiannya telah menjadi peraturan perundang-undangan hukum positif di Indonesia yang dijadikan acuan oleh hakim pengadilan agama dalam memutuskan perkara. Beberapa yurisprudensi pengadilan agama yang berkaitan dengan pembaruan hukum Islam di Indonesia:

\section{a. Putusan Pengadilan Agama Jakarta Selatan Nomor 1751/P/1989}

Pengadilan Agama Jakarta Selatan memutuskan dan melahirkan hukum baru yang tidak diatur dalam kitab fikih dan peraturan perundang-undangan tentang perkawinan di Indonesia, bahwa perkawinan yang dilangsungkan melalui telepon sah. Putusan ini telah memberikan nuansa baru dalam hukum perkawinan di Indonesia, yang pada awalnya tidak begitu direspon oleh masyarakat, tetapi sekarang telah banyak diikuti umat Islam di Indonesia untuk melaksanakan perkawinan apabila mengalami kesulitan dalam akad nikah. Sehingga putusan pengadilan agama ini dapat memberikan nuansa dalam pembaruan hukum Islam di Indonesia.

\section{b. Putusan Mahkamah Agung RI Nomor 51.K/AG/1999}

Mahkamah Agung memutuskan bahwa ahli waris non muslim berhak mendapatkan warisan berdasarkan wasiat wajibah yang kadar bagiannya sama dengan ahli waris lain yang

\footnotetext{
${ }^{9}$ Beberapa contoh permasalahan hukum keluarga yang muncul saat ini adalah perkawinan yang ijab kabulnya dilakukan melalui telepon, pembagian harta kewarisan yang berbeda dalam Alquran dengan melihat aspek sosial, pemberian harta warisan yang berbeda agama antara ahli waris dan pewaris, mengangkat anak angkat sebagai orang yang dapat menerima harta warisan melalui wasiat wajibah, wakaf dalam bentuk uang tunai. Akibat majunya teknologi dan perkembangan zaman dalam berbagai bidang ilmu pengetahuan mengharuskan negara untuk segera mengaturnya dalam peraturan perundang-undangan yang dapat memberikan solusi terhadap berbagai permsalahan agar tidak terjadi kekacauan di masyarakat.
} 
beragama Islam. Menempatkan ahli waris non muslim sejajar dengan ahli waris muslim merupakan hal yang baru dalam hukum kewarisan Islam yang berlaku di Indonesia.

c. Putusan Mahkamah Agung RI Nomor 131.K/AG/1992

Mahkamah Agung memutuskan bahwa harta wakaf tidak dapat ditukar atau dijual dengan benda lain, tetapi jika terpaksa harus ditukar atau dijual karena tidak ada manfaatnya lagi atau tidak strategis lagi, maka pelaksanaannya harus sesuai dengan ketentuan pasal 47 ayat (3) UU No. 5 Tahun 1960 tentang Pokok-pokok Agraria yang pelaksanaannya dituangkan dalam PP No 28 Tahun 1977 tentang perwakafan.

d. Putusan Mahkamah Konstitusi No.46/PUU-VIII/2010

Anak yang dilahirkan di luar perkawinan mempunyai hubungan perdata dengan ibunya dan keluarga ibunya serta dengan laki-laki sebagai ayahnya yang dapat dibuktikan berdasarkan ilmu pengetahuan dan teknologi dan/atau alat bukti lain menurut hukum mempunyai hubungan darah, termasuk hubungan perdata dengan keluarga ayahnya"; menurut MK pasal 43 ayat (1) UU No. 1 Tahun 1974 tentang Perkawinan yang mengatakan "anak yang dilahirkan di luar perkawinan hanya memiliki hubungan perdata dengan ibunya dan keluarga ibunya" bertentangan dengan UUD 1945, sehingga apabila dapat dibuktikan berdasarkan ilmu pengetahuan dan teknologi dan/atau alat bukti lainnya menurut hukum ternyata memiliki darah dengan ayahnya, maka dapat diakui memiliki hubungan perdata ayah biologis dan kelurga ayah biologisnya.

\section{ASPEK SOSIAL BUDAYA DALAM UNDANG-UNDANG}

Berikut akan diuraikan beberapa pasal yang ada dalam Undang-Undang Perkawinan yang ditetapkan berdasarkan faktor sosial dan maslahah:

a. Pencatatan perkawinan

Dalam pasal 2 ayat (2) UU No. 1 Tahun 1974 tentang Perkawinan menjelaskan bahwa ayat (1) perkawinan adalah sah apabila dilakukan menurut hukum masing-masing agama dan kepercayaan itu, ayat (2), tiap-tiap perkawinan dicatat menurut peraturan perundangundangan yang berlaku. 
Perintah pencatatan perkawinan yang termuat dalam undang-undang perkawinan tersebut tidak ditemukan dalam Alquran maupun hadis, hasil ijtihad ulama Indonesia tersebut didasarkan pada maslahah dan faktor sosial budaya kemudian diadopsi oleh negara dalam menyusun peraturan perundang-undangan tentang perkawinan. Dalam rangka menertibkan administrasi pernikahan, maka pemerintah membuat peraturan perundang-undangan yang mengatur tentang perkawinan. Pencatatan perkawinan itu sangat besar manfaatnya, selain sebagai bukti telah berlangsungnya perkawinan, juga untuk menjamin hak-hak yang terkait secara langsung terhadap terjadinya perkawinan tersebut, misalnya untuk menjamin hak-hak istri dan anak.

b. Larangan kawin antar agama

Dalam pasal 40 bagian c Inpres Presiden No. 1 Tahun 1991 tentang KHI, disebutkan bahwa dilarang melangsungkan perkawinan antara seorang pria dan seorang wanita karena keadaan tertentu, yaitu wanita yang tidak beragama Islam. Dari penjelasan pasal ini dapat dipahami bahwa tidak ada perkawinan antar agama. Bagi mereka yang ingin melaksanakan perkawinan harus memilih salah satu agama, baik itu memilih agama suami, atau pun memilih agama istri.

Pelarangan melangsungkan perkawinan beda agama itu karena memiliki mudh\}arat yang lebih besar dibanding manfaatnya. Perkawinan yang terjadinya antara pria muslim dan wanita non muslim mengakibatkan anak-anak yang dilahirkan dari perkawinan tersebut banyak memilih untuk menganut agama ibunya (non muslim). Oleh karena itu, ulama bersepekat untuk melarang perkawinan dengan wanita non muslim, lalu diadopsi oleh negara. c. Izin melaksanakan poligami dari Pengadilan Agama

Berdasarkan pasal 4 dan 5 UU No. 1 Tahun 1974 tentang Perkawinan menyebutkan bahwa seorang suami yang akan beistri lebih dari seorang wajib mengajukan permohonan ke Pengadilan di daerah tempat tinggalnya, dengan beberapa sebab seperti istri tidak dapat menjalankan kewajibannya sebagai seorang istri, istri mendapat cacat badan yang tidak dapat disembuhkan, istri tidak dapat melahirkan keturunan. Selain dari sebab-sebab tersebut, juga harus memiliki syarat-syarat lain, seperti persetujuan dari istri /istri-istri, adanya kepastian 
bahwa suami mampu menjamin keperluan-keperluan hidup istri-istri dan anak-anak mereka, dan adanya jaminan bahwa suami akan berlaku adil kepada istri-istri dan anak-anak mereka.

Meskipun Allah memberikan izin untuk melakukan poligami dengan pembatasan istri sampai empat, tetapi untuk menghilangkan mafsadah dan mengambil faedah, maka perlu ada izin dari pengadilan. Hal itu disebabkan karena berdasarkan fakta, tidak sedikit pelaku poligami menimbulkan konflik yang berkepanjangan, sehingga tujuan dari perkawinan tidak terwujud.

d. Harta bersama dalam perkawinan

Pada dasarnya konsep harta bersama merupakan adat istiadat yang berlaku dan berkembang di Indonesia. Konsep ini kemudian diadopsi oleh negara kemudian dimuat dalam undang-undang perkawinan.

Undang-Undang No. 1 Tahun 1974 pasal 35 ayat (1) tentang Perkawinan menyebutkan bahwa yang dimaksud dengan harta bersama adalah harta benda yang diperoleh selama perkawinan. Sedangkan dalam KHI pasal 85 menyebutkan bahwa adanya harta bersama di dalam perkawinan tidak menutup kemungkinan adanya harta milik masingmasing suami istri. Hukum Islam mengakui tentang adanya harta milik bagi setiap orang. Walaupun dalam pasal tersebut menyebutkan tentang harta bersama dalam perkawinan, tetapi tidak menolak adanya harta masing-masing dalam perkawinan. Oleh karenanya, apabila terjadi percerain, maka harta tersebut dibagi berdasarkan Islam dengan berpegang pada kaidah "tidak ada kemudaratan dan memudaratkan", sehingga yang ada adalah membagi harta berdasarkan prinsip keadilan.

e. Pembatasan usia perkawinan

Dalam UU No. 1 Tahun 1974 tentang Perkawinan pasal 7 menyebutkan bahwa perkawinan hanya diizinkan apabila, seorang pria telah berumur 19 tahun dan pihak wanita sudah mencapai 16 tahun. Di dlaam hukum Islam, tidak diatur secara jelas batas umur kawin, baik itu laki-laki maupun perempuan. Oleh karena itu, tidaklah mengherankan jika sebelum adanya undang-undang yang memberikan batasan dalam perkawinan, banyak sekali umat Islam di Indonesia yang menikah dalam usia yang masih sangat belia. 
Dalam perkawinan, tujuan perkawinan merupakan sesuatu yang harus diwujudkan, misalnya suasana ketentraman, kedamaian, kasih dan sayang. Akan tetapi sulit rasanya untuk mencapainya apabila perkawinan dilangsungkan dalam usia anak-anak. Diperlukan faktorfaktor yang lain untuk menggapainya seperti kedewasaan dan kemapanan dalam ekonomi. Walaupun Islam tidak melarang perkawinan anak-anak, akan tetapi perkawinan tersebut tidak dianjurkan. Sehingga penentuan batas usia untuk melangsungkan perkawinan sebagaimana yang termuat dalam undang-undang memiliki manfaat yang banyak terhadap terwujudnya perkawinan yang diharapkan.

f. Wasiat Wajibah dalah KHI

Dalam pasal 209 KHI menjelaskan bahwa, orang tua angkat yang tidak menerima wasiat diberikan wasiat wajibah sebanyak-banykanya 1/3 dari harta wasiat anak angkatnya, begitu juga dengan anak angkat yang tidak menerima wasiat, diberikan wasiat wajibah sebanyak-banyaknya 1/3 dari harta wasiat orang tua angkatnya.

Wasiat wajibah dalam pasal 209 Kompilasi Hukum Islam timbul untuk menyelesaikan permasalahan antara pewaris dengan anak angkatnya dan sebaliknya anak angkat selaku pewaris dengan orang tua angkatnya. Awalnya wasiat wajibah dilakukan karena terdapat cucu/cucu-cucu dari anak/anak-anak pewaris yang meninggal lebih dahulu daripada pewaris.

Dalam sistem hukum di Indonesia, wasiat wajibah menjadi kompetensi absolut dari pengadilan agama berdasarkan Undang-undang Nomor 7 Tahun 1989 tentang Pengadilan Agama berhubungan dengan Undang-undang Nomor 3 Tahun 2006 jo UU No. 50 tahun 2009 tentang Perubahan kedua Undang-undang Nomor 7 Tahun 1989 tentang Pengadilan Agama. Hakim yang dimaksud Ibnu Hazmin dalam kewarisan Islam di Indonesia dilaksanakan oleh hakim-hakim dalam lingkup pengadilan agama dalam tingkat pertama sesuai dengan kompetensi absolut sebagaimana diperintahkan undang-undang.

Dalam menentukan wasiat wajibah, secara yuridis formil, para hakim pengadilan agama menggunakan ketentuan Kompilasi Hukum Islam sebagaimana dinyatakan dalam Instruksi Presiden Nomor 1 Tahun 1991 tentang KHI. Secara yuridis formil ketentuan dalam 
Kompilasi Hukum Islam khususnya pasal 209 memahami bahwa wasiat wajibah hanya diperuntukan bagi anak angkat dan orang tua angkat.

\section{ASPEK SOSIAL DALAM FIKIH}

Faktor-faktor yang menjadi syarat dan mempengaruhi terjadinya interaksi sosial yaitu adanya kontak sosial dan komunikasi ${ }^{10}$. Selain faktor-faktor yang menjadi syarat terjadinya interaksi sosial, terdapat bentuk-bentuk interaksi antara lain berupa kerjasama (cooperation), persaingan (competition) dan pertikaian atau pertentangan (conflict) (Seorjono Soekanto, 2005:61). Dengan demikian, cakupan pembahasan proses sosial sangat berguna untuk menelaah dan mempelajari pelbagai masalah yang terjadi di dalam suatu masyarakat.

\section{KESIMPULAN}

Berdasarkan uraian di atas, maka beberapa hal yang menjadi kesimpulan mengenai karakteristik hukum Islam adalah sebagai berikut:

Hukum Islam memiliki karakter tersendiri yang berbeda dengan karakter sistem hukum yang berlaku di dunia, perbedaan ini disebabkan karena hukum Islam berasal dari Allah swt., sedangkan sistem hukum lainnya adalah kesepakatan antara manusia (buatan manusia). Para pakar hukum Islam telah banyak membahas tentang karakteristik hukum Islam, mereka berpedoman pada QS al-A'raf/7:157 yang maksudnya menyuruh orang mengerjakan yang ma'ruf dan mencegah yang mungkar, menghalalkan bagi mereka yang baik, dan mengharamkan yang buruk, dan membuang beban-beban dan belenggu-belenggu yang ada pada manusia. Di antara beberapa karakteristik hukum Islam yang ada yaitu; rabbaniyah, syumul, al-wasthiyah, dan insaniyah.

\footnotetext{
${ }^{10}$ Yang dimaksud kontak disini adalah pertemuan langsung yang terjadi antara dua individu, individu dengan kelompok, maupun kelompok dengan kelompok. Sedangkan yang dimaksud dengan komunikasi yaitu seseorang memberikan respon atau tafsiran pada perilaku orang lain yang menjadi lawan komunikasi, baik itu respon dalam bentuk pembicaraan, gerakan badan (bahasa tubuh) maupun dalam bentuk sikap. Komunikasi merupakan sesuatu yang harus terjadi diantara individu dalam menciptakan interaksi sosial, karena tanpa adanya komunikasi, tidak tercipta interaksi sosial dalam masyarakat.
} 
Faktor-faktor sosial budaya yang senantiasa berkembang karena perkembangan ilmu pengetahuan dan teknologi telah merasuki berbagai pemikiran hukum Islam, khususnya di Indonesia. Hal tersebut disebabkan karena tuntutan perubahan zaman, tidak hanya itu pemikiran dalam hukum Islam juga dimaksudkan untuk merespon berbagai perkembangan sosial budaya dari para pelaku pelaksana hukum. Ada beberapa metode penetapan hukum Islam yang dipengaruhi oleh aspek pendekatan sosial di Indonesia, yaitu; penetapan hukum Islam melalui fikih, penetapan hukum Islam melalui undang-undang, penetapan hukum Islam melalui yurisprudensi, dan penetapan hukum Islam melalui fatwa.

\section{DAFTAR PUSTAKA}

Ahmad, Amrullah, dkk. (1996). Dimensi Hukum Islam dalam Sistem Hukum Nasional. Cet. I; Jakarta: Gema Insani Press.

Ali, Zainuddin (2014). Sosiologi Hukum. Cet. 8; Jakarta: PT. Sinar Grafika.

Al-Qardhawi, Yusuf (1995), Karakteristik Islam Kajian Analitik, Surabaya: Rislah Gusti.

Ash-Shiddieqy, Hasbi (1997) Pengantar Hukum Islam. Edisi kedua, Cet. I; Semarang: PT. Pustaka Rizki Putra.

Ash-Shiddieqy, Hasbi (2001). Filsafat Hukum Islam. Semarang: PT. Pustaka Rizki Putra.

Bisri, Hasan Cik (2004). Pilar-Pilar Penelitian Hukum Islam dan Pranata Sosial. Jakarta: Rajawali Pers.

Ghofur, Anshori Abdul, dan Yulkarnain Harahab (2008). Hukum Islam Dinamika dan Perkembangannya di Indonesia. Cet. I; Yogyakarta: Kreasi Total Media Yogyakarta.

Haq, Hamka (2000) Falsafat Usul Fikih. Cet. I; Makassar: Yayasan al-Ahkam.

Mahsun Fuad (2011), Hukum Islam dan Sosial. Vol. 11 No. 2, Nopember.

Maman, Suherman Ade (2006). Pengantar Perbandingan Sistem Hukum. Cet. II; Jakarta: Rajawali Pers.

Manan, Abdul (2006) Reformasi Hukum Islam di Indonesia. Cet. I; Jakarta: PT. Raja Grafindo Persada.

Musyahid, Achmad (2012). Melacak Aspek-aspek Sosiologis dalam Penetapan Hukum Islam. Cet. I; Makassar: Alauddin University Press.

Shihab, Umar (1996). Hukum Islam dan Transformasi Pemikiran. Cet. I; Semarang: Dina Utama Semarang.

Siswanto, Eko (2012). Deradikalisasi Hukum Islam dalam Perspektif Maslahat. Cet. I; Makassar: Alauddin University.

Soekanto, Soerjono (2004). Pokok-pokok Sosiologi Hukum. Jakarta: RajaGrafindo.

Soekanto, Soerjono(2005). Sosiologi Suatu Pengantar. Jakarta: PT. Raja Grafindo Persada.

Sudarsono (1999). Kamus Hukum. Cet. II; Jakarta: PT. Rineka Cipta.

Supardin (2011). Materi Hukum Islam. Cet. I; Makassar: Alauddin University Press.

Usman, Iskandar (1994). Istihsan dan Pembaharuan Hukum Islam. Cet. I; Jakarta: PT. Raja Grafindo Persada. 